\title{
Research on Technology Competencies in EFL Language Instructors: Technology-Pedagogy-Content in Language Teaching
}

\author{
Rodrigo Tovar Viera ${ }^{1}$, Diego Ismael Velasco Sánchez \\ Technical University of Cotopaxi, Ecuador ${ }^{1}$ \\ University of the Armed Forces ESPE, Ecuador ${ }^{2}$ \\ Correspondence email: rodrigo.tovar@utc.edu.ec
}

\section{Background:}

Abstract

Living in the digital era where the information and communication technologies (ICTs) have extensively changed the way of teaching, language instructors, in particular, should be computer literate to put their technical knowledge into practice in such a way they effectively integrate technology into language learning classrooms.

\section{Methodology:}

The research contextualizes teachers' beliefs and competencies of using the Technological Pedagogical Content Knowledge (TPCK) in teaching English as a foreign language. The study is an extension of previous research carried out by Tovar et at., (2019), and Tovar (2019). It applied a survey-based questionnaire, an unstructured interview, and classroom observations for data collection. The assessment instruments were administrated to EFL language instructors, who work in the Language Center at the Technical University of Cotopaxi.

Findings:

Results revealed that a high percentage of the EFL language instructors are not familiar with the use of the TPCK model and its integration into their classroom practices. This support the claim that teachers probably have technological knowledge, but they are not well-prepared to combine teaching resources and appropriate pedagogical methods for language teaching and learning.

\section{Conclusions:}

The study hopes that research outcomes arise linguistic implications and pedagogical applications for developing teachers' TPCK competencies when integrating technology in EFL classroom settings. Limitations, as well as considerations for further research, are discussed.

Keywords: TPCK competency; classroom practices; computer literate.

\begin{tabular}{|c|c|c|}
\hline DOI & : & http://dx.doi.org/10.24903/sj.v5i1.414 \\
\hline Received & : & January 2020 \\
\hline Accepted & : & March 2020 \\
\hline Published & : & April 2020 \\
\hline Copyright Notice & $:$ & $\begin{array}{l}\text { Authors retain copyright and grant the journal right of first publication with the } \\
\text { work simultaneously licensed under a Creative Commons Attribution } \mathbf{4 . 0} \\
\text { International License that allows others to share the work with an acknowledgement of } \\
\text { the work's authorship and initial publication in this journal. } \\
\text { (c) (i) (?) }\end{array}$ \\
\hline
\end{tabular}




\section{INTRODUCTION}

In the 21 st century, the inclusion of educational technologies into classroom practices has been taken as an integral aspect of teacher education (Luu and Freeman, 2011; Windschitl, 2009). Tools like forums, videoconferencing, and e-learning platforms put up with the acquisition of knowledge and skills. Wachira \& Keengwe (2011) state that technology embedded in line with the pedagogical practices and content knowledge of the subject is the base for language development. Nonetheless, teachers require "an understanding of how particular topics, problems, or issues are organized, represented and adapted to the diverse interests and abilities of learners" (Shulman, 1986, p.8). That is, they need solid know-how of using digital tools (Mishra \& Koehler, 2006), planning and reflecting on technology integration (Hilton, 2016), and reconnecting technology to both subject-matter knowledge and pedagogical content according to learners' needs (Koehler \& Mishra, 2015). Thus, "how learners' linguistic and cultural backgrounds can contribute when using technology, what facilitates or hinders the acquisition of language and the development of language competence" should be taken into account to see if technology use meets learning goals (Van Olphen, 2008, p.6-7) .

Regarding technological competency, Hofer \& Grandgenett (2012) recognize that teachers' technological knowledge contributes to better integrate technology in education. Atun \& Usta (2019), therefore, emphasized that using TPCK lessons (technology, pedagogy and content knowledge) in teacher education, enhance learning outcomes as long as enriched technological activities are included in the process. Similarly, Tanak (2018) discovered that technology-based courses provide teachers better opportunities to incorporate materials into their subject matter. Technology then offers learners a wide variety of sources to learn and practice the language inside or outside of the classroom (Ahmadi, 2018). As technology integration depends on the method used to facilitate language acquisition (Ahmadi, 2017), teaching instructions must be well-designed; otherwise, students may have worthless experiences. Then "a new level of technical competency and literacy is needed for teachers to use technology in ways that enhance students learning" (Kereluik, Mishra \& Koehler, 2011, p.13), by encouraging learners to find by themselves appropriate language activities that integrate computer technology to feedbacking and feedforwarding (Genç İlter, 2015). Therefore, modeling activities with available technology, selecting appropriate pedagogy, developing specific content activities, applying practical learning instructions and designing authentic learning tasks are the foci of technology integration (Schrum et al., 2007; Tai, 2013).

Research on the use of Information and Communication Technologies (ICTs) in education has been carried out to uncover the synchronization of technology with pedagogy 
and content (Atun \& Usta, 2019; Graham, Burgoyne, Smith, Clair \& Harris, 2009; Niess, 2005; Miller, 2008; Mishra, Kereluik, Shin, \& Graham, 2014). Although the accessibility to digital tools and internet connections continues increasing in some educational institutions, particularly in Ecuador, the use of ICTs for academic goals is poorly developed. It is because technology, in teacher education, is often seen as an isolated component, independent from pedagogy and content (Koehler et al., 2007) or because some teachers do not probably have the necessary competence or enough experience to apply technology in their teaching (Niess, 2005; Miller, 2008; Hechter \& Vermette, 2013). Accordingly, there is a limited understanding of the conceptual basis of technology in education (Koehler \& Mishra, 2008). The present research investigates teachers' beliefs and competencies of integrating the TPCK framework in teaching English. To reach this goal, the following research questions will be addressed: What is the TPCK competency level in English Foreign Language (EFL) instructors? What digital tools and how frequently those tools are used inside and outside their classrooms? and to what extent the use of technology contributes to classroom language learning?

\section{METHODOLOGY}

For the nature of the small sample size and methodology used, the study is descriptive in design with a quantitative approach. Therefore, it is an exploratory, diagnostic and descriptive research study that adopts the assessment instrument developed by Schmidt et al., (2009) to gather information about (a) teachers' technology competence, (b) knowledge at using the TPCK framework in the classroom practices, and (c) the frequency of using technology for academic purposes. Accordingly, the 16 EFL instructors who constitute the English teaching staff of the Language Center, were surveyed on a 5 point Likert scale $(1=$ Low, 2 = Basic, 3 = Intermediate, $4=$ Upper, and $5=$ Strong) to collect data on the items $\mathbf{a}$ and b above-mentioned whilst the 5 point Likert scale $(1=$ never, $2=$ once a month, $3=$ once a week, 4 = once a day, and $5=$ more than once a day) surveyed item c. Additionally, the study carried out classroom observations and teachers' interviews.

Data research collection consists of a sequential and baseline procedure. In the first stage, 16 EFL teachers were surveyed; then, based on the data analysis of the survey, four teachers teaching English at A1 and A2 levels were randomly selected to be observed and interviewed in order to gain knowledge of their technological competency. In the second stage, eight digital resources were introduced to the four teachers, as of jimdosite.com (web hosting service), VOKI (recording app), Comic Strip (designing app), Spotlight (radio program), Ego4u (Grammar Online), Kahoot (game-based learning platform), Koala Text (reading 
comprehension), Voscreen (short video clips) so they can explore these sources before integrating them into their classrooms. Finally, the four teachers who received orientations in the management of those digital sources were observed to identify the improvement of their technological competency and the integration of technology into their teaching practices.

The triangulation of instruments and sources used to gather information was doable, as the researcher applied a qualitative approach supported by quantitative data from surveys to account for the validity and reliability of the data analysis. Thus, the study consisted of the segmentation of the data collected from the interview and class observations such as coding and categorization of meaningful and relevant information related to the research goals. The excel data analyzer statistic tool performed the analysis. So, the data analysis was based on teachers' technology skills, thus teacher's self-perception, types and frequent use of technology, and some visions on integrating the TPCK components were the foci of the study to establish the domains of the TPCK competency.

\section{FINDINGS}

The study investigates teachers' self-perceptions on the synergy of technology, pedagogy, and content knowledge. Data in table 1, illustrates how frequent teachers use technology. Unlike video-chats, text messages were used more than once a day outside their teaching $(\mathrm{SD}=4.88)$, followed by emails $(\mathrm{SD}=2.28)$, and Facebook $(\mathrm{SD}=0.88)$. Using technology in teacher education, the majority of the surveyed use publishing platforms more than once a day $(\mathrm{SD}=4.88)$ compared to the institutional rented platform, Moodle $(\mathrm{SD}=1.88)$. Weblogs were reported to be the third frequent tool used inside classrooms ( $\mathrm{SD}=-2.11)$, whereas computer-assisted language learning (CALL) was the fourth instructional tool to create collaborative space for language learning ( $\mathrm{SD}=-6.11)$.

Table 1. Frequency of technology used by EFL teachers

\begin{tabular}{cccccccccc}
\hline & \multicolumn{4}{c}{ In-Side } & \multicolumn{4}{c}{ Out-Side } \\
& $\begin{array}{c}\text { Publishing } \\
\text { Platform }\end{array}$ & Moodle & Weblogs & CALL & $\begin{array}{c}\text { Video- } \\
\text { chat }\end{array}$ & Facebook & Email & Text & Others \\
messaging & \\
\hline $\boldsymbol{f}$ & 16 & 13 & 9 & 5 & 4 & 12 & 14 & 16 & 11 \\
mean & 5 & 4.06 & 2.81 & 1.56 & 1.25 & 3.75 & 4.37 & 5 & 3.44 \\
$\boldsymbol{S D}$ & 4.88 & 1.88 & -2.11 & -6.11 & -7.11 & 0.88 & 2.88 & 4.88 & -0.11 \\
\hline
\end{tabular}

The table below (2) presents an overview of the results obtained from the preliminary analysis of teachers' knowledge and ability to use and integrate technology in their teaching. As we can see from the data, $75 \%$ of the respondents revealed an average understanding of using TPCK whereas $13 \%$ of EFL teachers indicated having either strong or low competency when integrating TPCK in teaching languages. We can infer, then, that very few EFL teachers have strong knowledge of the TPCK components but show difficulties in assisting technology 
into their pedagogical practices. Over half of those surveyed reported the appropriate level of PK (56\%) and PCK (50\%); nonetheless, they show a low level of self-efficacy when accounting tech-based instructions. What stands out in the data is that the knowledge on digital videos and computers is considered teachers' TK. Digital literacy includes more than that; rather, it integrates all instructional materials, ranging from the whiteboard to a wide variety of advanced technologies utilized in the online or offline learning environment.

Table 2. EFL teachers' TPCK competency

$\begin{array}{cccc}\text { Dimensions } & \begin{array}{c}\text { Strong } \\ \text { knowledge }\end{array} & \begin{array}{c}\text { Moderate } \\ \text { knowledge }\end{array} & \begin{array}{c}\text { Low } \\ \text { Knowledge }\end{array}\end{array}$

\begin{tabular}{lcccccc}
\multicolumn{1}{c}{ Category } & $f$ & $\%$ & $f$ & $\%$ & $f$ & $\%$ \\
\hline TK (Technological knowledge) & 8 & 50 & 7 & 44 & 1 & 6 \\
CK (Content knowledge) & 8 & 50 & 8 & 50 & - & - \\
PK (Pedagogical knowledge) & 6 & 38 & 9 & 56 & 1 & 6 \\
PCK (Pedagogical-Content knowledge) & 7 & 44 & 8 & 50 & 1 & 6 \\
TPK (Technological-Pedagogical knowledge) & 8 & 50 & 7 & 44 & 1 & 6 \\
TCK (Technological-Content knowledge) & 7 & 44 & 8 & 50 & 1 & 6 \\
TPCK (Technological-Pedagogical-Content & 2 & 13 & 12 & 75 & 2 & 13 \\
knowledge) & & & & & & \\
\hline
\end{tabular}

Further analysis shows that females outperformed in all the TPCK components $(M=22$, $f=18.71)$. However, they reported a moderate level of knowledge in comparison with the advanced level of expertise indicated by male teachers $(M=26, f=22.65)$. It was hypothesized that participants with advanced levels of technological expertise were highly competent to integrate the three knowledge domains. Nonetheless, the classroom observations showed the opposite side of the continuum. Although few participants responded they have a low level of competency in all the seven knowledge domains $(M=7, f=5.37)$, it does not mean that the rest of the surveyed had the right knowledge and competence in the related domains.

Table 3 revealed that the majority of the surveyed indicate that technology, in many ways, helps improving language teaching. Nonetheless, the third part of those subjects reported basic technological knowledge of using new websites and solving technical inconvenience. Although data on table 3 showed that over half of participants informed positive outcomes at using technology and computerized device, it was seen that they struggled technological problems in their teaching. This result is in line with Cando et al. (2018) and Tanak, (2018) who found lower levels of technological competence in EFL teachers to handle digital sources into language learning environments. 
Table 3. Technology competency and its knowledge domains

\begin{tabular}{|c|c|c|c|c|c|c|c|c|c|c|c|c|}
\hline \multirow[b]{2}{*}{ I can or I know... } & \multicolumn{3}{|c|}{$\underline{\text { Basic }}$} & \multicolumn{3}{|c|}{ Intermediate } & \multicolumn{3}{|c|}{ Upper } & \multicolumn{3}{|c|}{ Strong } \\
\hline & $f$ & $S D$ & $\%$ & $f$ & $S D$ & $\%$ & $f$ & $S D$ & $\%$ & $f$ & $S D$ & $\%$ \\
\hline a) learn technology easily. & 8 & 1.3 & 50 & 3 & -1.8 & 18 & 5 & -1.5 & 31 & - & - & - \\
\hline $\begin{array}{l}\text { b) solve my own digital and technical } \\
\text { problems, as computer-mediated } \\
\text { communication. }\end{array}$ & 8 & 1.3 & 50 & 4 & -0.8 & 25 & 4 & -2.5 & 25 & - & - & - \\
\hline $\begin{array}{l}\text { c) keep up with important new technologies } \\
\text { (e.g. CALL) }\end{array}$ & 2 & -4.8 & 12 & 6 & 1.2 & 37 & 8 & 1.5 & 50 & - & - & - \\
\hline $\begin{array}{l}\text { d) frequently use technology to language } \\
\text { teaching (e.g. Moodle, blogs) }\end{array}$ & - & - & - & 7 & 2.2 & 43 & 9 & 2.5 & 56 & - & - & - \\
\hline $\begin{array}{l}\text { e) several websites about new technology, } \\
\text { for instance, blogs, wikis. }\end{array}$ & 9 & 2.3 & 56 & 4 & -0.8 & 25 & - & - & - & 3 & 2.4 & 18 \\
\hline
\end{tabular}

\section{DISCUSSION}

With the use of technology, students become active learners, not just consumers. When using technology in teaching, for instance, comic strip, Kahoot, language learners developed problem-solving and critical thinking, and also transferred knowledge from other learning experiences to accomplish the task. The inclusion of educational technologies in language teaching, therefore, functioned as an integral aspect of teacher education in such way learners' attitude towards learning was more active and dynamic than traditional one. This gain makes sense in the context of the teacher preparation because, at this point, students were actively enrolled in their learning. Nonetheless, consistent with the literature (Hechter \& Vermette, 2013; Atun \& Usta, 2019; Koehler \& Mishra, 2008), observation classes, interview, and survey, this research found that there is limited knowledge of using digital tools to assist their teaching. The possible reason could be that teachers' pedagogical knowledge is not according to their technological and content knowledge. Additionally, their practical professional development to exploit the pedagogical benefits of digital tools in teacher education is deficient.

Although over half the percentage of the subjects interviewed had experienced the use of technological tools, smartboards and flashcards were reported as the most frequently used materials. However, during the observation classes, they reported having basic knowledge of how to combine technology with pedagogy and content in classroom settings. Accordingly, there is clear evidence of lower competence in the use of the TPCK components, namely TCK, TPK, and PCK. The classroom observations and the data gathered from the surveyed questionnaire supports the claim that teachers probably have technological knowledge, but they are not well-prepared to combine it into their pedagogical practices. This claim confirms that lower levels of self-efficacy in integrating technology in teaching are associated with teachers' digital literacy and attitudes toward tech-based instructions (Lee \& Tsai, (2010)

The majority of teachers faced difficulties in developing their technological competence to take part in the digital society as users of the technology. They do not know how to take 
advantage of the digital tools available online. Indeed, the lack of technological knowledge limits the proper use of technology for academic purposes. Teachers sometimes may reveal self-efficacy with TPCK, but limited experiences related to professional development, technology exploration, and learners' engagement in learning (Ansyari, 2015). In this way, Koehler et al., (2007) suggest before using the TPCK framework to gain knowledge of what makes concepts difficult or easy to learn and how technology can positively guide the way of building on existing knowledge and teaching materials (p.743). What stands out in the study is that, having a computer and internet connection in the classroom and following a textbook and the instructional material provided by the publishing company are determiners of teachers' level of technology use, which to some extent, are misinterpreted as enough recurring technological practices to effectively integrate TPCK components in language teaching.

Although there are lots of digital tools freely available online, research outcomes report a limited knowledge of how to select the best ones to achieve the learning objectives set out in the lesson plans. It can thus be suggested that English lessons integrate technology as the learning will be more dynamic and contextualized (Kereluik et al., 2011). However, its integration is sometimes challenging since it is not enough understanding the content to be taught, but rather how to explain that content via technology, integrating cognitive, social and developmental theories of learning (Koehler et al., 2007). Accordingly, teachers need continuous professional development opportunities to integrate technology in their teaching.

Even though most of the EFL teachers showed a reasonable level of understanding of the three basic categories (TPC), the research findings revealed difficulties at the moment of integrating these three knowledge domains into the educational process. As a result, English teachers' current technology-related knowledge is deficient, as in the studies of Cando et al. (2018) and Tanak, (2018). Education in the $21^{\text {st }}$ century requires the intersection between technology, pedagogy, and content as learners develop linguistic and communicative competence through e-learning environments. Nevertheless, its implementation requires much effort than usual because there is no "one best way" to integrate technology into the curriculum; rather, integration efforts must be creatively designed for a particular subject domain.

In today's increasingly digital world, teachers require a sophisticated understanding of the technology, pedagogy, and content knowledge to monitor students' knowledge development (Hofer \& Grandgenett, 2012). That is, there is no guarantee of learning whether primary technological sources like interactive whiteboards are not well-used in language teaching (Hilton, 2016; Genç İlter, 2015). If teachers cannot infer what technology-related 
knowledge is inherent to each content and how it should be integrated into their teaching, then learning outcomes will be unrewarding. These findings are further in line with Chai, Koh and Tsai (2010), who state that teachers' lack of direct teaching experiences limited the fruitful integration of technology in different learning environments. Nonetheless, in our case, the appropriate dynamics of classroom intervention and the introduction of digital sources connected to TPCK framework allowed both teachers and learners, to integrate technology into the language learning settings, on the one hand, and to have positive attitudes toward language learning, on the other side. The latter, in language learners at levels A1 and A2, particularly since they were actively engaged within the learning process. That is, technology integration ignites learners' interest in language and language learning.

\section{CONCLUSION}

For teachers to effectively use educational technology into their classrooms, it is required a comprehensive understanding of the synergy between technology, pedagogy, and content. Accordingly, adapting teachers' skills to the new digital classroom practices could be described as one of the most challenging issues in teacher education. The primary reason for such skill difficulty is because EFL teachers see technology, pedagogy, and content as independent components of each other. Despite the classroom observations, survey, and interview research techniques deal with numerical counting, frequencies, and percentages, the research outcomes are at an early stage in understanding how the TPCK components are combined in language teaching and integrated with teacher's pedagogical practices. Nonetheless, the findings set out evidence of teachers' technological practices and their selfperceptions on using the TPCK framework in education. In this way, we can have a clear idea of how to make technology more pedagogically sound from our teaching practices. That is, teachers, require more practical continuous professional development opportunities to effectively support the pedagogical integration of technology into their language classrooms.

In the advancement of the digital era, particularly in Ecuador, training programs have been implemented and introduced to be in line with the new educational advances. However, in spite of implementing those academic and professional development programs, the country is still far behind the effective integration of technology in education. It is because of the complexity and scarce training programs related to the use of TPCK as a conceptual framework that connects three areas of expertise within a specific context. That is, the intersections between technology, pedagogy, and content require not only understanding the content itself but also developing technical skills for teaching specific content. The findings of this study 
suggest practical continuous professional development courses so that teachers understand TPCK dimensions and gain opportunities to teach in more technologically and pedagogically enriched classrooms.

\section{REFERENCES}

Ahmadi, M. R. (2017). The Impact of Motivation on Reading Comprehension. International Journal of Research in English Education, 2(1), 1-7. https://doi.org/10.18869/acadpub.ijree.2.1.1

Ahmadi, M. R. (2018). The Use of Technology in English Language Learning: A Literature Review. International Journal of Research in English Education, 3(2), 115-125. https://doi.org/10.29252/ijree.3.2.115

Ansyari, M. F. (2015). Designing and Evaluating A Professional Development Programme for Basic Technology Integration in English as a Foreign Language (EFL) Classrooms. Australasian Journal of Educational Technology, 31(6), 699-712. https://doi.org/10.14742/ajet.1675

Atun, H., \& Usta, E. (2019). The Effects ff Programming Education Planned with TPACK Framework on Learning Outcomes. Participatory Educational Research (PE), 6(2), 2636. Retrieved from http://dx.doi.org/10.17275/per.19.10.6.2

Graham, C. R., Burgoyne, N., Cantrell, P., Smith, L., Clair, L. S., \& Harris, R (2009). TPACK Development in Science Teaching: Measuring the TPACK confidence of in-service science teachers. Tech Trends, 53(5), 70-79.

Retrieved from http://galleries.lakeheadu.ca/uploads/4/0/5/9/4059357/measureing_tpack_confidence.pdf

Chai, C. S., Koh, J. H. L., \& Tsai, C. C. (2010). FacilitatingPpre-serviceTteachers' Development of Technological, Pedagogical, and Content Knowledge (TPACK). Educational Technology \& Society, 13(4), 63-73. Retrieved from https://www.learntechlib.org/p/52307/

Cando, F., Tituaña, I., Bermardo Cando, B., \& Lema, Y. (2018). Pedagogical technological competence of content in the areas of language and literature. Congress of Science and Technology, 13(1), 178-181. Retrieved from https://docplayer.es/87683262-Revistacongreso-de-ciencia-y-tecnologia-memorias-sesiones-tecnicas-junio-2018.html

Hechter, R.. P., \& Vermette, L. A. (2013). Technology Integration in K-12 Science Classrooms: An analysis of barriers and implications. Themes in Science and Technology Education, 6(2), 73-90. Retrieved from https://eric.ed.gov/?id=EJ1131093 
Hilton, J. T. (2016). A Case Study of the Application of SAMR and TPACK for Reflection on Technology Integration into Two Social Studies Classrooms. The Social Studies, 107(2), 68-73. https://doi.org/10.1080/00377996.2015.1124376

Hofer, M., \& Grandgenett, N. (2012). TPACK Development in Teacher Education. Journal of Research on Technology in Education, 45(1), 83-106. https://doi.org/10.1080/15391523.2012.10782598

Genç İlter, B. (2015). How does Technology Affect Language Learning Process at an Early Age? Procedia - Social and Behavioral Sciences, 199, 311-316. https://doi.org/10.1016/j.sbspro.2015.07.552

Koehler, M. J., \& Mishra, P. (2015). TPACK (Technological Pedagogical Content Knowledge). In J. Spector (Ed.), The SAGE Encyclopedia of Educational Technology (pp. 783-786). https://doi.org/10.4135/9781483346397.n318

Koehler, M. J., Mishra, P., Kereluik, K., Shin, T. S., \& Graham, C. R. (2014). The Technological Pedagogical Content Knowledge Framework. In J.M. Spector et al. (Ed.), Handbook of Research on Educational Communications and Technology (pp. 101-111). https://doi.org/10.1007/978-1-4614-3185-5_9

Koehler, M. J., Mishra, P., \& Yahya, K. (2007). Tracing The Development of Teacher Knowledge in A Design Seminar: Integrating Content, Pedagogy and Technology. Computers \& Education, 49(3), 740-762. https://doi.org/10.1016/j.compedu.2005.11.012

Koehler M. J., \& Mishra, P. (2008). Introducing Technological Pedagogical Knowledge. In I. AACTE (Ed.), The Handbook of Technological Pedagogical Content Knowledge for Educators (pp. 1-16). New York: Routledge/Taylor \& Francis Group for the American Association of Colleges of Teacher Education.

Kereluik, K., Mishra, P., \& Koehler, M. J. (2011). On Learning to Subvert Signs: Literacy, Technology and the TPACK Framework. Winter. The California Reader, 44(2), 12-18.

Lee, M. H. \& Tsai, C. C. (2010). Exploring Teachers' Perceived Self-Efficacy and Technological Pedagogical Content Knowledge With Respect To Educational Use Of The World Wide Web. Instructional Science: An International Journal of the Learning Sciences, 38(1), 1-21. Retrieved from https://eric.ed.gov/?id=EJ869653

Shulman, L. S. (1986). Those Who Understand: Knowledge Growth in Teaching. Educational Researcher, 15(2), 4-14. 
Luu, K., \& Freeman, J. G. (2011). An Analysis of The Relationship Between Information and Communication Technology (ICT) and Scientific Literacy in Canada and Australia. Computers \& Education, 56(4), 1072-1082. https://doi.org/10.1016/j.compedu.2010.11.008

Schrum, L., Thompson, A., Maddux, C., Sprague, D., Bull, G., \& Bell, L.(2007). Research on The Effectiveness of Technology In Schools: The roles of pedagogy and content. Contemporary Issues in Technology and Teacher Education, 7(1), 456-460. Retrieved from https://www.learntechlib.org/primary/p/26278/.

Windschitl, M. (2009). Cultivating 21st Century Skills in Science Learners: How systems of teacher preparation and professional development will have to evolve. National Academies of Science Workshop on 21st Century Skills, 1-23. Washington: Mark Windschitl, University of Washington.

Miller, S. M. (2008). Teacher Learning for New Times: Repurposing New Multimodal Literacies and Digital Video Composing for Schools. In \& D. L. J. Flood, S.B. Heath (Ed.), Handbook of research on teaching literacy through the communicative and visual arts (pp. 441-460). New York, NY: International Reading Association/Simon \& Schuster Macmillan.

Mishra, P., \& Koehler M. J. (2006). Technological Pedagogical Content Knowledge: A Framework for Teacher Knowledge. Teachers College Record, 108(6), 1017-1054. https://doi.org/10.1111/j.1467-9620.2006.00684.x

Niess, M. L. (2005). Preparing Teachers to Teach Science and Mathematics with Technology: Developing a technology pedagogical content knowledge. Teaching and Teacher Education, 21(5), 509-523. https://doi.org/10.1016/j.tate.2005.03.006

Wachira, P., \& Keengwe, J. (2011). Technology Ntegration Barrieris: Urban school mathematics teachers' perspectives. Journal of Science Education Technology, 20(1), 1725. Retrieved from https://www.learntechlib.org/p/52555/.

Schmidt, D. A., Baran, E., Thompson, A. D., Mishra, P., Koehler, M. J., \& Shin, T. S. (2009). Technological Pedagogical Content Knowledge (TPACK). Journal of Research on Technology in Education, 42(2), 123-149.

https://doi.org/10.1080/15391523.2009.10782544

Tai, S.-J. D. (2013). From TPACK-in-Action Workshops to English classrooms: CALL competencies developed and adopted into classroom teaching (Doctoral dissertation). Iowa State University, Iowa, USA. 
Tanak, A. (2018). Designing TPACK-Based Course for Preparing Student Teachers to Teach Science with Technological Pedagogical Content Knowledge. Kasetsart Journal of Social Sciences, 1-7. https://doi.org/10.1016/j.kjss.2018.07.012

Tovar, R. (2019). Examining Technological Pedagogical Content Knowledge Competency. IV International congress, CSIU: Science, society and university research. Pontifical Catholic University of Ecuador, 22-24 October. Ambato, Ecuador.

Tovar, R., Chacon, M., Cisneros, C., \& Noroña, M. (2019). The TPCK Framework for Technology Integration in Language Teaching. In R. V. M. (CEO) (Ed.), First International Congress of Teacher Education Development-CIDU. Quevedo, Ecuador: Quevedo State Technical University.

Van Olphen, M. (2008). TPCK: An Integrated Framework for Educating World Language Teachers. In et al. A. A. of C. for T. E. Mary C. (Ed.), Handbook of technological pedagogical content knowledge (TPCK) for educators (pp. 107-128). New York, NY: Routledge for the American Association of Colleges for Teacher Education. 